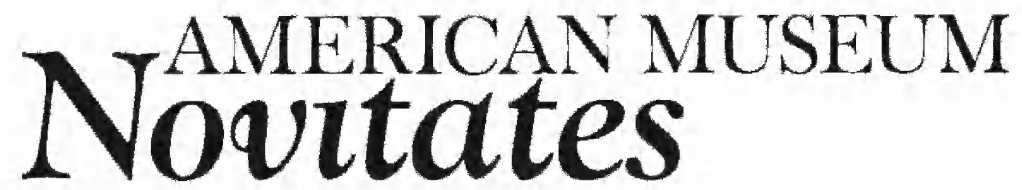

PUBLISHED BY THE AMERICAN MUSEUM OF NATURAL HISTORY CENTRAL PARK WEST AT 79TH STREET, NEW YORK, NY 10024 Number 3595,9 pp., 30 figures

December 12, 2007

\title{
On Nyetnops, a New Genus of the Spider Subfamily Nopinae (Araneae, Caponiidae) from Brazil
}

\author{
NORMAN I. PLATNICK ${ }^{1}$ AND ARNO A. LISE ${ }^{2}$
}

\begin{abstract}
A new caponiid genus, Nyetnops, is described to contain a remarkable new species, $N$. guarani from Brazil. These spiders, which have a bizarrely elongated male palp, have the subsegmented tarsi typical of the Nopinae, but lack the additional leg modifications found in those taxa. They may therefore represent the sister group of the other described nopine genera.
\end{abstract}

\section{INTRODUCTION}

The present paper, the fifth in a series on the spider family Caponiidae, is the second to deal with members of the Nopinae, a seemingly monophyletic group whose members are easily recognized by their subsegmented tarsi (there is at present no evidence that the remaining, non-nopine genera, the so-called Caponiinae, constitute a single monophyletic group). The type genus, Nops MacLeay (1839), is also marked by a variety of additional, bizarre leg modifications, including the enormous elon- gation of the unpaired claw into a structure that reaches as far dorsally as do the paired claws (and is apparently associated with the presence of a translucent pulvillar lobe), the elaboration of a translucent keel under the anterior metatarsi (Platnick, 1995: figs. 6, 7), and the presence of a distal, translucent, fanshaped extension of the intersegmental membrane separating the anterior metatarsi and tarsi (Platnick: 1995, figs. 8-11).

The new Brazilian species treated here (figs. 1, 2) has subsegmented tarsi but none of the other leg modifications found in

\footnotetext{
${ }^{1}$ Peter J. Solomon Family Curator, Division of Invertebrate Zoology, American Museum of Natural History; Adjunct Professor, Department of Biology, City College, City University of New York; Adjunct Professor, Department of Entomology, Cornell University; Adjunct Senior Research Scientist, Center for Environmental Research and Conservation, Columbia University (platnick@amnh.org).

${ }^{2}$ Laboratório de Aracnologia, Faculdade de Biociências, Pontifícia Universidade Católica do Rio Grande do Sul, Brazil (lisearno@pucrs.br).
} 

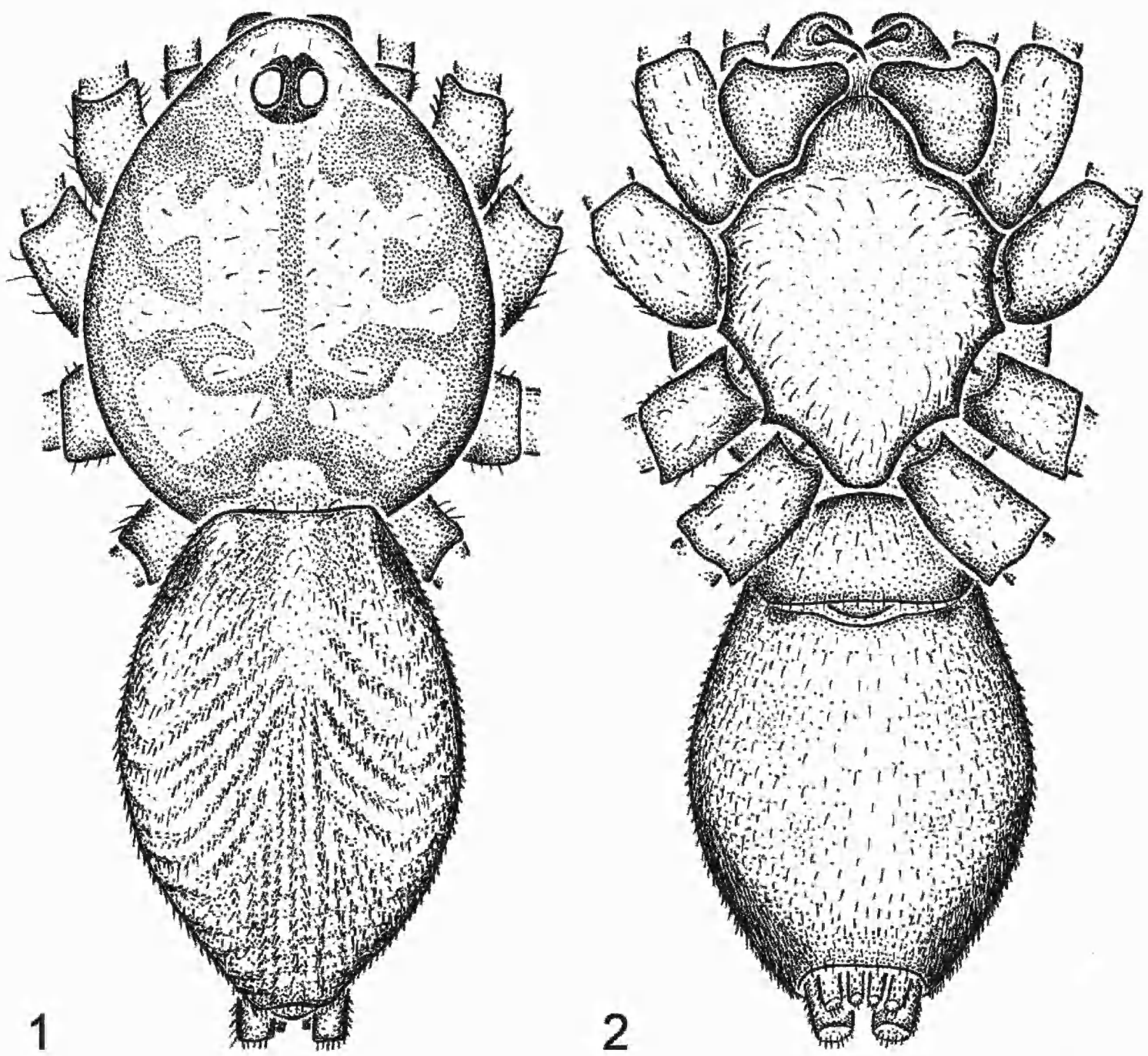

Figs. 1, 2. Nyetnops guarani, new species, male cephalothorax and abdomen. 1, Dorsal view. 2. Ventral view.

Nops. As the other known nopine genera (Orthonops, Tarsonops, and Nopsides, all described by Chamberlin, 1924) all share at least some of those additional leg modifications, it seems likely that this new species, which we assign below to the new genus Nyetnops, represents the sister group of all the other described nopines. We have seen specimens of a few other apparently undescribed Neotropical species that may prove to be members of Nyetnops (or at least other basal nopine genera), but better samples of those taxa, and additional study, will be needed to determine their status.
Although the legs of the Brazilian species are relatively unmodified (for a nopine), the male palp is extraordinary (figs. 3-5). Not only is the embolus elongated, thickened, protruding, and distally widened, the entire bulb has become so elongated that the limits of the embolus per se can be discerned only by differences in the cuticle (figs. 25-28).

The available specimens are also of interest because they may help resolve a puzzle with regard to the genus Caponina Simon (1891). Brignoli (1977) reported on a series of specimens collected at Nova Teutonia, Santa Catarina, Brazil, by F. Plaumann, which he 


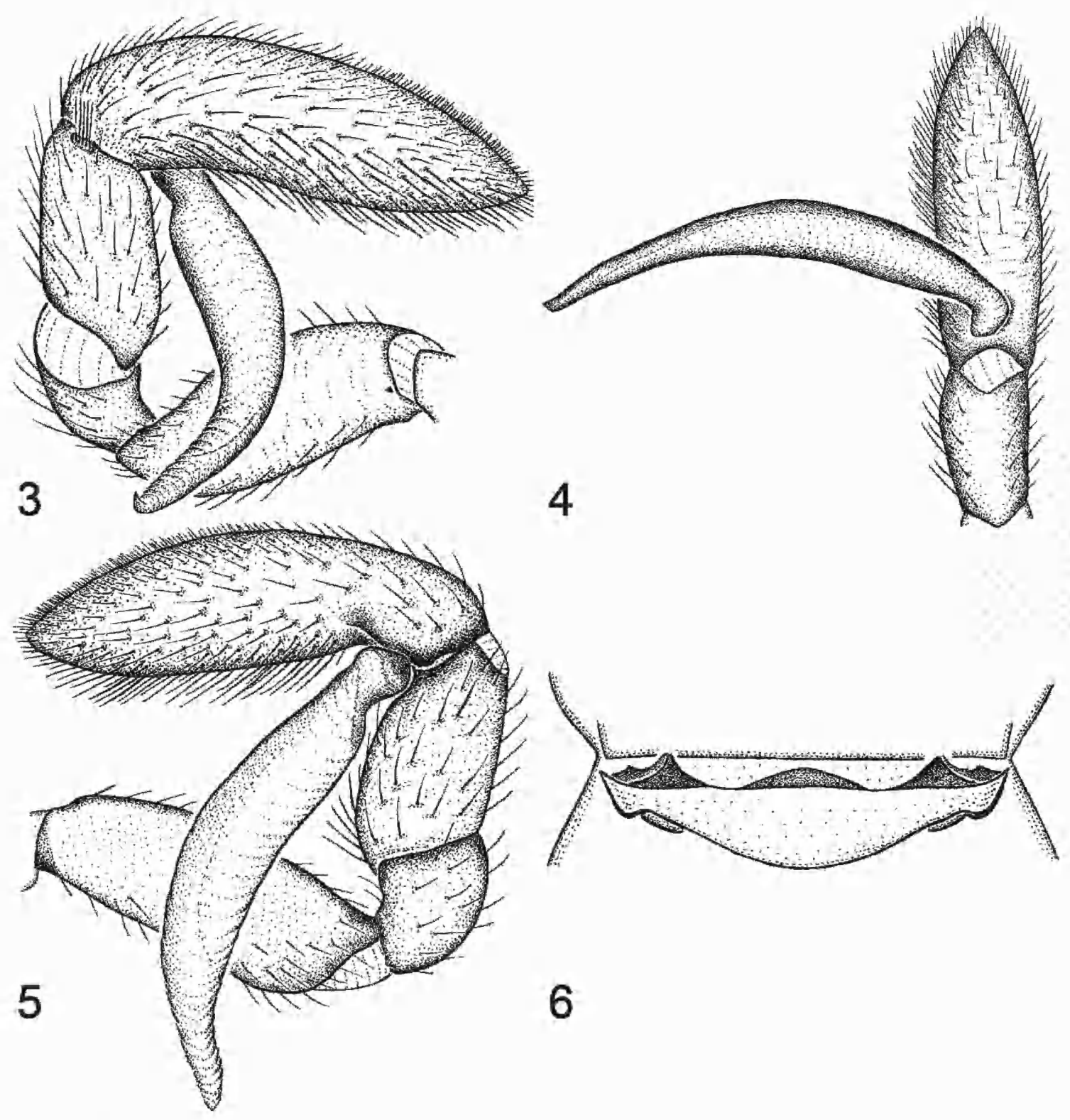

Figs. 3-6. Nyetnops guarani, new species. 3. Left male palp, prolateral view. 4. Same, ventral view. 5. Same, retrolateral view, 6. Internal female genitalia, dorsal view,

attributed to Bruchnops melloi Birabén (1951), now placed as a junior synonym of Caponina notabilis (Mello-Leitão, 1939). That series included various adults and juveniles that were reported to have either six, four, or two eyes. During a revision of Caponina (Platnick, 1994a) a few specimens were encountered with teratological eye numbers (three or five), but no two-eyed specimens of that genus were found in any of the samples examined then for subsequently).

In connection with the present revision, we received for study from the Institut Royal des Sciences Naturelles de Belgique, Brussels, a sample of caponiids also collected at Nova Teutonia by Plaumann, which proved to be a mixed lot. Some of the material did indeed belong to $C$, notabilis, as expected, but one 
female, which has only two eyes, belongs instead to the new species treated here. This suggested that Brignoli's series may also have been mixed, that his two-eyed specimens actually belong to Nyetnops, and that there are actually no two-eyed Caponina.

The difficulty with this hypothesis is that Brignoli (1977: 610) indicated that the only adult female he examined (collected in November, 1958) has only two eyes. Through the courtesy of Drs. Bernd Hauser and Peter Schwendinger, we have now also been able to re-examine some of the specimens from the Muséum d'Histoire Naturelle, Geneva, that were studied by Brignoli. His adult female is correctly identified, but clearly has six eyes, rather than two; on the other hand, at least one of the two-eyed juveniles clearly has subsegmented anterior tarsi, and hence cannot possibly belong to $C$. notabilis. Thus, there seems no doubt that the two genera do indeed co-occur at Plaumann's locality.

The material reported on below comes from the collections of the American Museum of Natural History (AMNH), the Institut Royal des Sciences Naturelles de Belgique, Brussels (IRSN, courtesy of Dr. Léon Baert), the Museu de Ciências Naturais, Porto Alegre (MCN, courtesy of Dr. Erica Buckup), the Museu de Ciências e Tecnologia da Pontifícia Universidade Católica do Rio Grande do Sul, Porto Alegre (MCTP), and the Museu de Historia Natural do Capão da Imbuia, Curitiba (MHCI, courtesy of Drs. Ricardo Pinto-da-Rocha and Antonio Brescovit). Assistance with illustrations and plates was supplied by Mohammad Shadab, Estevam Luís Cruz da Silva, and Steve Thurston. All measurements are in millimeters.

\section{SYSTEMATICS}

Nyetnops, new genus cies.

Type Species: Nyetnops guarani, new spe-

Eтymology: The generic name is an arbitrary combination of letters, masculine in gender because of the ending -ops.

Diagnosis: Members of the genus can be separated from the previously known caponiid genera as follows: from Caponia Simon (1887),
Calponia Platnick (1993), Diploglena Purcell (1904), Caponina, Notnops Platnick (1994b), Taintnops Platnick (1994b), and Tisentnops Platnick (1994b) by the presence of subsegmented tarsi, from Nopsides by having only two eyes, from Nops by having normal, rather than greatly elongated, unpaired tarsal claws, from Tarsonops by having entire metatarsi and only two tarsal subsegments, and from Orthonops by lacking a metatarsal keel and a process extending from the intersegmental membrane between the metatarsi and tarsi of legs I and II.

Description: Small caponiids with carapace light orange, bearing paler yellow markings in labyrinthine arrangement (fig. 1), oval, widest at front of coxae III, only gradually narrowed anterior of eyes; pars cephalica elevated at rear (more so in males than in females), without elevated ocular tubercle; pars thoracica high anteriorly, steeply sloping posteriorly, with only very slight submarginal elevations opposite coxal bases, separated by very slight submarginal depressions opposite coxal interspaces; cuticle mostly smooth, with low sculpturing consisting of roughly hexagonal cells restricted to area of thoracic groove, with few long, dark setae in ocular area and on pars cephalica; thoracic groove obsolete; clypeus without pair of rounded elevations at lateral corners, almost three times as high as eyes. Two large, dark eyes separated by less than their diameter, posterior margins situated at about one-eighth of carapace length, united by oval ring of black pigment. Chelicerae with median lamina terminating in toothlike tip; distal half of median edge of paturon occupied by white membranous lobe; lateral surface flattened, with long series of stridulatory ridges (figs. 7, 8); pick for stridulatory ridges at base of prolateral side of palpal femur (figs. 3, 9). Endites (figs. 10, 11) light orange, wide, strongly convergent, not protuberant posteriorly, rounded distally, males with protuberant anterolateral corners (fig. 2), anterior surface distally with strong serrula consisting of single tooth row (fig. 12), proximally without strong setae originating from enlarged bases. Labium light orange, broad, triangular, fused to sternum along deep posterior groove. Sternum light orange, oval, cuticle glabrous, bearing scattered weak setae; cephalothoracic 


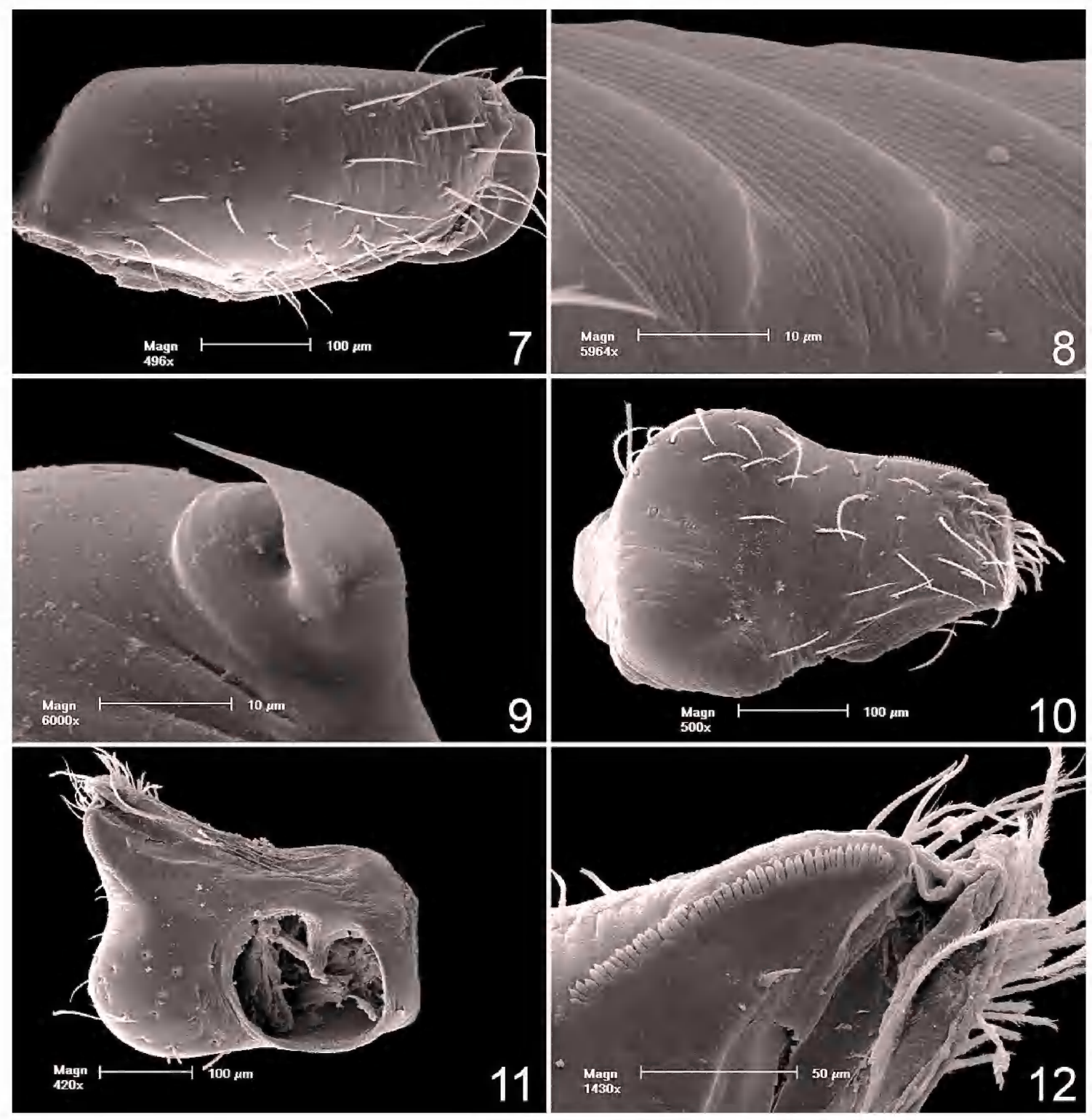

Figs. 7-12. Nyetnops guarani, new species, male. 7. Chelicera, oblique anterior view. 8. Cheliceral striculatory ridges, oblique lateral view. 9. Stridulatory pick on palpal femur, prolateral view. 10. Endite, anterior view. 11. Endite, posterior view. 12. Serrula, oblique posterior view.

membranes with three weakly sclerotized epimeric sclerites dorsal of coxae I, II, and III plus IV; sternal margin rebordered, with long, triangular extensions reaching to middle of coxae II-IV and shorter intercoxal projections; epimeric sclerites not fused with sternal extenstions. Female palpal tarsus only very slightly expanded, without claw, with numer- ous long setae, including conspicuous, dense patch of setae prolaterally and dorsal pad of shortened setae. Leg formula 4123; legs orange, without spines, with many setae; cuticle ridged, granulate (fig. 23); metatarsi entire, without translucent median, longitudinal keel or distal, translucent, fan-shaped extension originating from intersegmental 

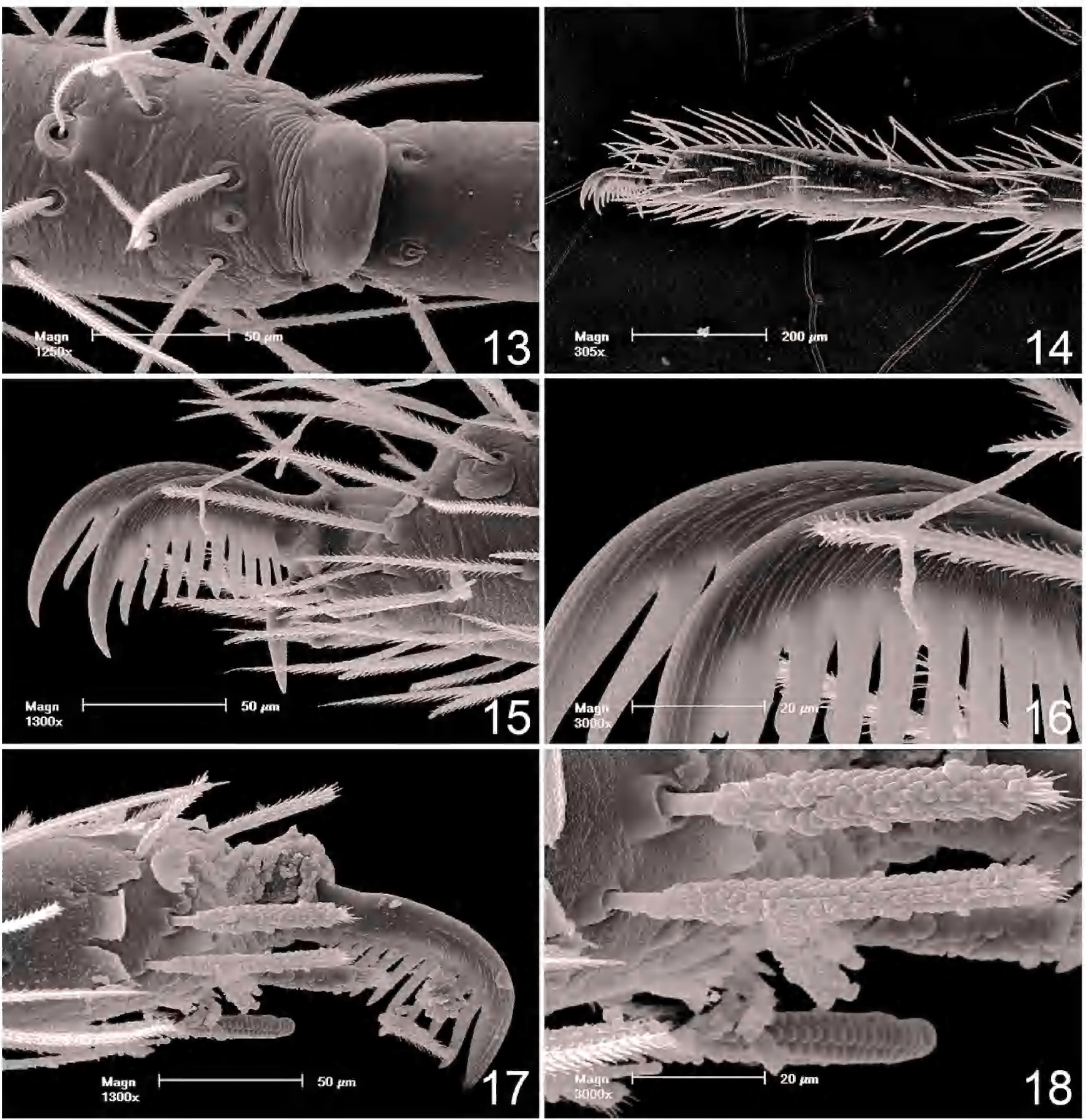

Figs. 13-18. Nyetnops guarani, new species, male. 13. Metatarsus and tarsus I, dorsal view. 14. Same, lateral view. 15. Claws of leg I, lateral view. 16. Same, detail. 17. Claws of leg IV, lateral view. 18. Setae accompanying claws of leg IV, lateral view.

membrane (figs. 13, 14); tarsi subsegmented (fig. 14), proximal subsegment slightly longer than distal one; tarsi with three claws (figs. 15-18); paired claws with about 7-9 teeth, most distal of which are largest (tooth number varies among legs, and between proand retroclaw of each leg); unpaired claw without teeth, distinctly protruding from onychium. Tarsal organ exposed, with con- centric ridges (fig. 24); metatarsi with slit sense organs near depressed area bearing tiny, central pore (figs. 21, 22); trichobothria (figs. 19, 20) present on tibiae, metatarsi, and tarsi, their bases with semicircular rim bearing slight longitudinal ridges. Abdomen pale gray dorsally, with hairline pale markings, lighter ventrally, with two pairs of respiratory spiracles clustered around epigastric groove, tra- 

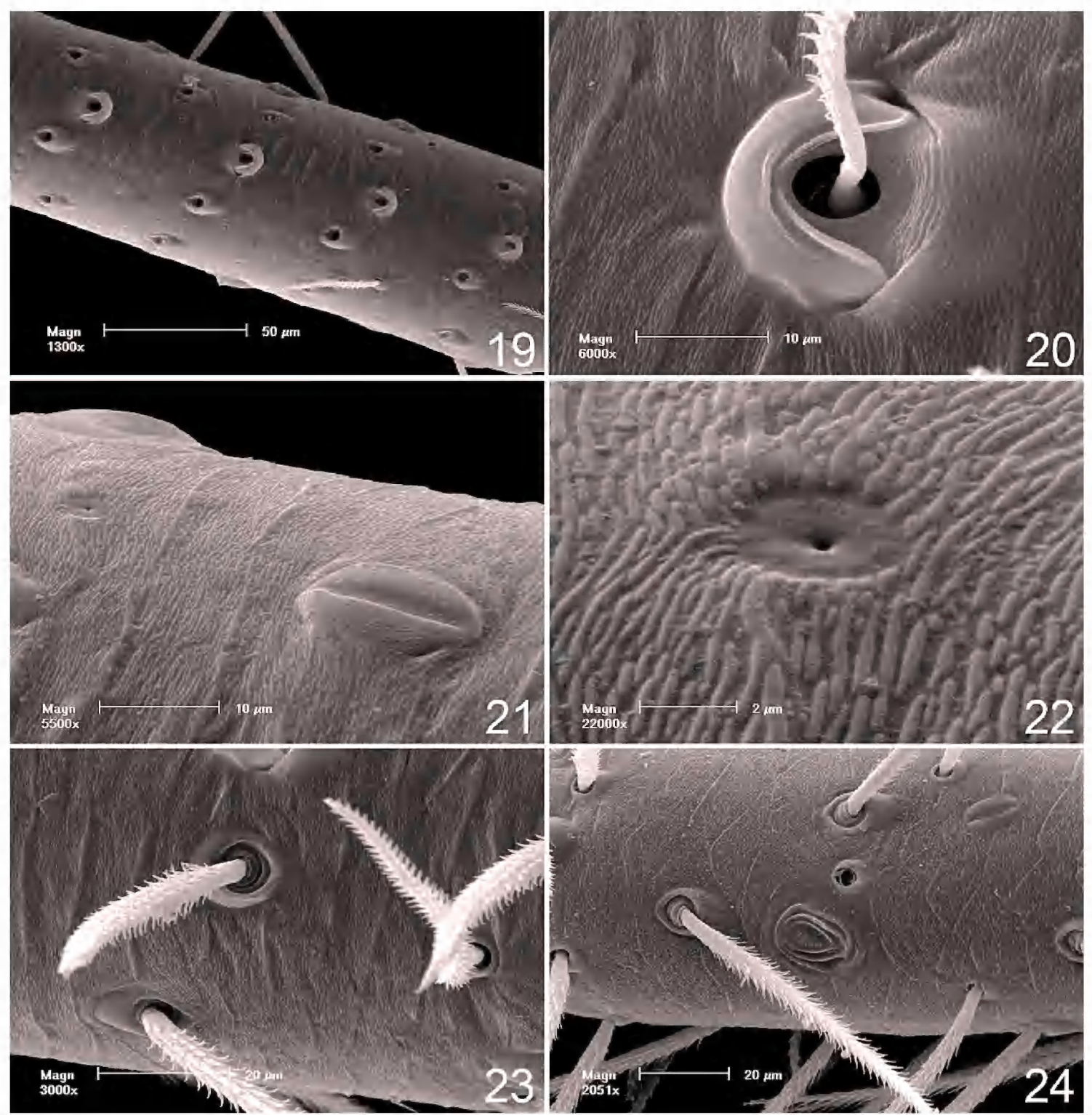

Figs. 19-24. Nyetnops guarani, new species, male. 19. Metatarsus IV, dorsal view. 20. Trichobothrium from metatarsus IV, dorsal view. 21. Metatarsus I, slit sense organ and pore, dorsal view. 22. Same, detail of pore. 23. Cuticle, leg I, dorsal view. 24. Tarsal organ, leg I, dorsal view.

cheal arrangement unknown. Spinnerets in typical caponiid arrangement; judging from light microscopy only, anterior laterals apparently with single large major ampullate gland spigot and two smaller piriform gland spigots in female, male with only major ampullate gland spigot evident; posterior medians apparently with 3-5 long-shafted aciniform gland spigots, females with enlarged, poster- iorly situated single wide spigot; posterior laterals with several aciniform gland spigots. Male palpal femur without dorsal tubercle; patella short; tibia not excavated ventrally, distal promargin with short row of stiff, pale setae; cymbium (figs. 29, 30) only slightly swollen, with distinct dorsal pad of short setae; palpal bulb longer than cymbium, distinction evident between bulb 

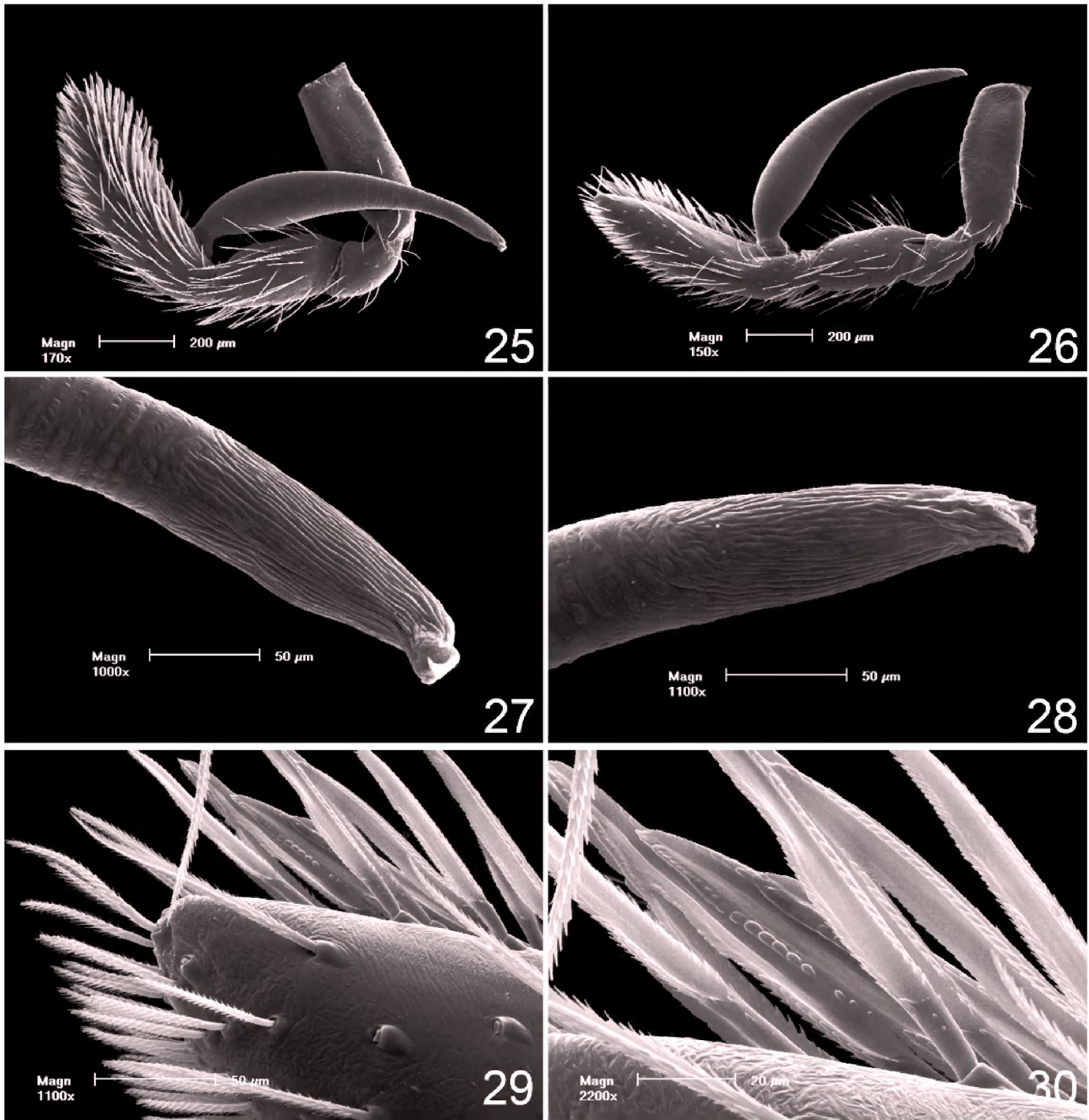

Figs. 25-30. Nyetnops guarani, new species, male. 25. Left male palp, prolateral view. 26. Same, retrolateral view. 27. Apex of embolus, prolateral view. 28. Same, retrolateral view. 29. Tip of cymbium, retrolateral view. 30. Same, detail of setae.

and embolus only by differences in cuticular surface (figs. 25-28). Internal female genitalia consisting of membranous, transverse anterior receptaculum bearing lateral sclerotized elements, without median receptaculum extending posteriorly (fig. 6).

DisTRIBUTION: Known with certainty only from southeastern Brazil.

\section{Nyetnops guarani, new species} Figures 1-30

Types: Male holotype and female allotype from Fóz do Córrego Três Barras, Rio Guarani, Três Barras do Paraná, Paraná, Brazil (Feb. 24-Mar. 24, 1993; A. B. Bonaldo), deposited in MCN. 
ETymology: The specific name is a noun in apposition taken from the type locality.

Diagnosis: The enormously elongated palpal bulb of males (figs. 3-5, 25-28) and the anteriorly excavated lateral epigynal sclerotizations of females (fig. 6) are diagnostic.

Male (holotype): Total length 3.27. Carapace 1.31 long, 1.22 wide, pale orange with pair of large, prominent, longitudinal lighter markings on elevated portion at rear of pars cephalica, in labyrinthine pattern elsewhere on carapace. Endites with distinctly protruding anterolateral corners. Abdomen with hairline pale markings. Palpal tibia with promarginal row of stiff setae; entire bulb enormously elongated (figs. 3-5, 25-28).

Female (allotype): Total length 3.46. Carapace 1.34 long, 1.18 wide. Coloration as in male. Endites without protruding corners. Internal genitalia with low sclerotized triangles situated near origin of posterior tracheae (fig. 6).

Other Material Examined: BRAZIL: Paraná: Fóz do Córrego Três Barras, Rio Guarani, Três Barras do Paraná, Feb. 24-Mar. 24, 1993 (A. B. Bonaldo, MCN 23414, AMNH), 17ð; Foz do Rio Capoteiro, Pinhão, Oct. 25, 1991 (R. Pinto-da-Rocha, M. R. Lopes, MHCI), 1 đ; Usina Hidrelétrica, Reserva Rio dos Touros, Pinhão, Feb. 22, 1992 (R. Pinto-da-Rocha, MCN 25919), 3 ô, Mar. 1992 (R. Pinto-da-Rocha, MHCI), 1 ô; Usina Hidrelétrica, Ribeirão Estreito, Pinhão, Jan. 21-Feb. 1992 (R. Pinto-da-Rocha, MHCI), $3 \hat{\delta}$, Mar. 1992 (R. Pinto-da-Rocha, M. Segalla, MCN 25918, 25920), 8 శึ. Rio Grande do Sul: Vicente Dutra, all pitfalls, T. F. Trescher: Jan. 8, 2006 (MCTP 19528), 3 f , 1 \& , Jan. 23, 2006 (MCTP 19529), 15 $\delta, 3$ ㅇ, Feb. 7, 2006 (MCTP 19530), $7 \hat{\jmath}$, Feb. 22, 2006 (MCTP 19531), $6 \hat{\jmath}$, Mar. 9, 2006 (MCTP 19532), $9 \hat{\jmath}, 2$ ㅇ. Santa Catarina: Nova Teutonia, Aug. 1957 (F. Plaumann, IRSN), 1 \% .

Distribution: Southeastern Brazil.

\section{REFERENCES}

Birabén, M. 1951. Dos especies nuevas del género Bruchnops Mello-Leitão (Araneae-Caponiidae). Revista de la Sociedad Entomológica Argentina 15: 57-64.

Brignoli, P.M. 1977. Ragni del Brasile III. Note su Bruchnops melloi Biraben e sulla posizione sistematica dei Caponiidae (Arachnida, Araneae). Revue Suisse de Zoologie 84: 609-616.

Chamberlin, R.V. 1924. The spider fauna of the shores and islands of the Gulf of California. Proceedings of the California Academy of Sciences 12: 561-694.

MacLeay, W.S. 1839. On some new forms of Arachnida. Annals and Magazine of Natural History 2: 1-14.

Mello-Leitão, C.F.de. 1939. Les arachnides et la zoogéographie de l'Argentine. Physis (Buenos Aires) 17: 601-630.

Platnick, N.I. 1993. A new genus of the spider family Caponiidae (Araneae, Haplogynae) from California. American Museum Novitates 3063: 1-8.

Platnick, N.I. 1994a. A revision of the spider genus Caponina (Araneae, Caponiidae). American Museum Novitates 3100: 1-15.

Platnick, N.I. 1994b. A review of the Chilean spiders of the family Caponiidae (Araneae, Haplogynae). American Museum Novitates 3113: 1-10.

Platnick, N.I. 1995. A revision of the spider genus Orthonops (Araneae, Caponiidae). American Museum Novitates 3150: 1-18.

Purcell, W.F. 1904. Descriptions of new genera and species of South African spiders. Transactions of the South African Philosophical Society 15: 115-173.

Simon, E. 1887. Observation sur divers arachnides: synonymies et descriptions. Annales de la Société Entomologiques de France, series 6, 7(Bull.): 158-159, 167, 175-176, 186-187, 193-195.

Simon, E. 1891. On the spiders of the island of St. Vincent. Part 1. Proceedings of the Zoological Society of London 1891: 549-575. 


Complete lists of all issues of the Novitates and the Bulletin are available at World Wide Web site http://library.amnh.org/pubs. Inquire about ordering printed copies via e-mail from scipubs@amnh.org or via standard mail from: American Museum of Natural History, Library-Scientific Publications, Central Park West at 79th St., New York, NY 10024. TEL: (212) 769-5545. FAX: (212) 769-5009. 